\title{
The characteristics of stability test using Bantak as the main
} aggregate

\author{
Mohamad Aqif 1, *, Md. Masudul Haque ${ }^{2}$, Wasiu Akande Ahmad ${ }^{3}$ \\ ${ }^{1}$ Department of Civil Engineering, Faculty of Engineering, Universitas Negeri Yogyakarta, Yogyakarta, 55281, \\ Indonesia \\ ${ }^{2}$ Postgraduate Student, Department of Mathematics, National University, Gazipur-1708 Address, Bangladesh \\ ${ }^{3}$ African Regional Centre for Space Science and Technology Education, English, IIe-Ife, 220282, Nigeria \\ E-mail: elhaji.akiv@gmail.com* \\ * Corresponding Author
}

ABSTRACT

ARTICLE INFO

This study aims to determine the characteristics of the stability test using Bantak as the main material. Fundamental studies in terms of the characteristics of Stability values include Density (Density), Flow (melting), VIM (Void in Mix), VMA (Void in Mineral Aggregate), VFB (Void Filled Bitumen), and Marshall Quotient (MQ). This study uses an experimental test method consisting of different bitumen content variants, respectively, 5\%, $5.5 \%, 6 \%, 6.5 \%$, and $7 \%$. Each variant consists of three samples of the test object. The research was carried out at the building materials laboratory, Faculty of Engineering, Universitas Negeri Yogyakarta. The implementation stages include inspection of AC 60/70, an inspection of aggregates (fine aggregate and coarse aggregate), an inspection of fillers, and manufacturing mixed specimens and stability tests with various characteristics. The results of the research showed that the average value of stability, density, flow, void in the mix, void mineral aggregate, void filled bitumen, and Marshall quotient was $1156.44 \mathrm{~kg}, 2.33 \mathrm{gr} / \mathrm{cc}, 3.07 \mathrm{~mm}, 5.20 \%, 13.92 \% 60.10 \%$ and 377.28 $\mathrm{kg} / \mathrm{mm}$. Finally, Bantak aggregate can be used as an alternative in the manufacture of hot asphalt mixtures because the research performance data meet the requirements for accepting Indonesian national standards. Its abundant availability makes Bantak a solution in exploiting Merapi material, which is very influential on the environmental impact and improves residents' economy in the quarry area.

This is an open-access article under the CC-BY-SA license.

\author{
Article history \\ Received: \\ 25 July 2021 \\ Revised: \\ 21 August 2021 \\ Accepted: \\ 25 August 2021 \\ Keywords \\ Aggregate \\ Bantak \\ Characteristics \\ Stability
}

\section{Introduction}

Yogyakarta is an area with abundant natural resources. This can be indicated by the presence of Mount Merapi, which is still active along with its lava eruptions, also releasing millions of cubic meters of volcanic material consisting of sand, gravel, and rocks. Simultaneously in the eruption process, one type of material tends to be ignored because it is considered not of equal quality with rocks or other materials, known as Bantak. Bantak is one of the eruption materials of Mount Merapi, which has a low level of violence. Bantak has not been widely used by the 
community, even though Merapi releases $70 \%$ of all materials.

Bantak stone is a porous rock material that has a low level of hardness. Bantak aggregate is not well-known among the general audience, and its use is still very minimal, especially for construction materials. From a business perspective, it's reasonable., people tend to prefer Merapi's material as the main exploitation because it is prominent and has excellent performance as a building material, pavement structure, and civil engineering fields.

Various research on Bantak aggregates is still limited to studies on material characteristics and their use as basic materials [1]-[8]. However, it is rare to find this aggregate function an alternative for forming flexible pavement as light, heavy, or medium of structures like [9], [10]. Thus, the main focus in this paper is to test the characteristic of Bantak aggregate as the primary component in hot mix mixtures, which will be very useful for accelerating the development of village infrastructure in the quarry area. In addition, from an economic point of view, it will be very influential because of the availability of easily obtained materials, avoiding various legal problems in the aspect of construction implementation [11], as well as minimizing any material procurement discrepancies. Fig. 1 shows the research procedure.
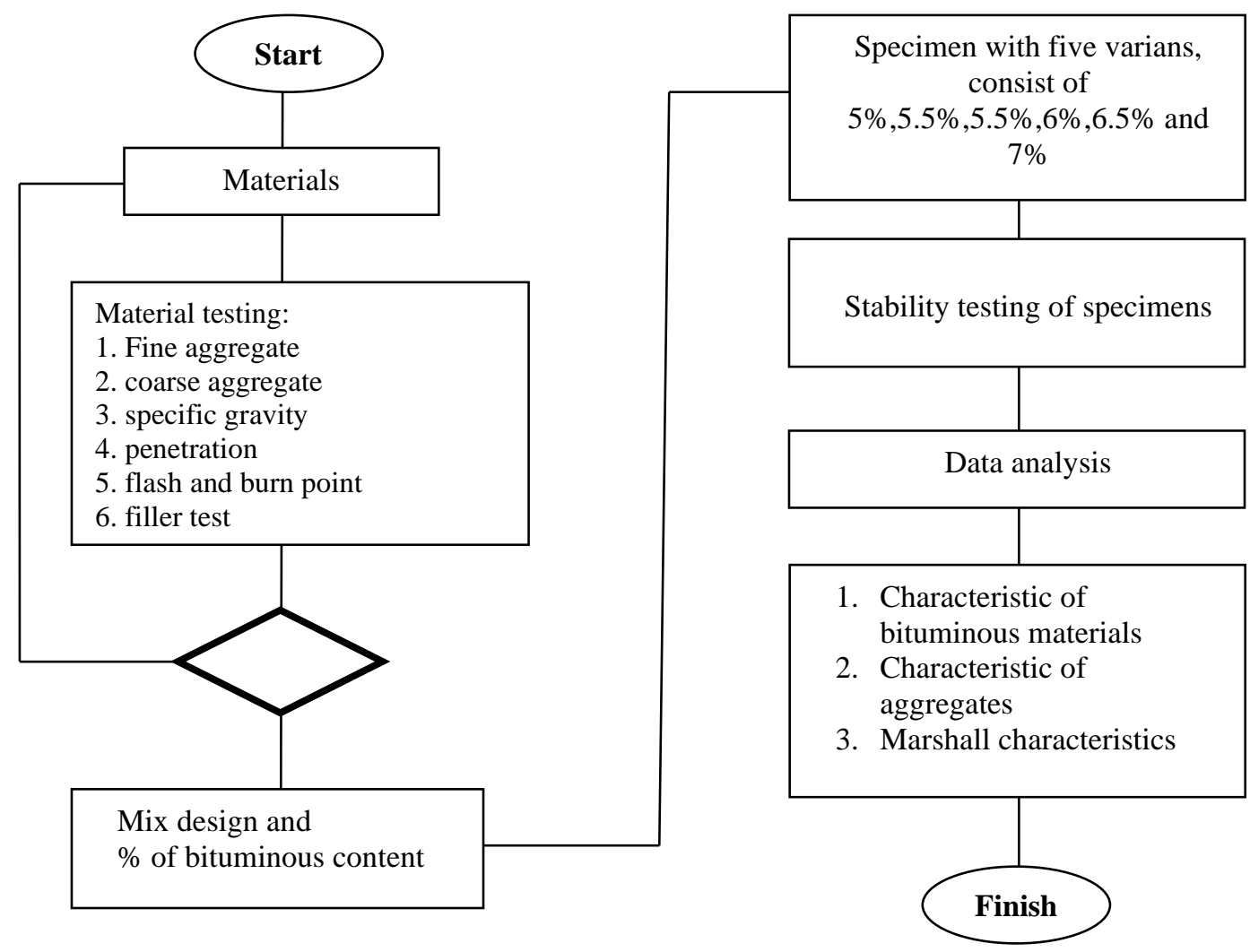

Fig.1. Research flowchart

Finally, various tests to ensure the quality of the material were carried out; hence Bantak's capabilities could be accepted in scientific studies. The series of density tests, the size of the voids in the mixture, the material's resistance, and the aggregate effect on the mixed voids are studied in-depth in this paper. In addition, the combination of binders becomes an independent variable that directly determines the quality of the material in terms of material fatigue. 


\section{Method}

This research used experimental laboratory methods. The research flowchart is presented in Fig. 1. The research materials used were Bantak coarse aggregate, Bantak fine aggregate, Bantak filler material, AC 60/70 binder. The equipment used in this experimental test is a bitumen material inspection test apparatus (one set of penetration, one set of softening point test, flash and burn point test, specific gravity test). Aggregate inspection test equipment consists of a set of sand filters. Aggregate characteristic test: molding, compactor, Ejector, Marshall test, Oven. The material inspection, including coarse aggregate, fine aggregate, and asphalt, refers to [12]-[16]. Test specifications can be seen as follows.

(1) Coarse aggregate test: Coarse aggregate for this design is aggregate that passes a 3/4" sieve and is retained on a $2.36 \mathrm{~mm}$ sieve or no. 8 sieve. Coarse aggregate for testing purposes shall consist of crushed stone or crushed gravel and shall be provided in nominal sizes [12].

(2) Fine aggregate test: fine aggregate from each source must consist of natural sand or stone crushing results that pass filter no. 8 and retain on filter no. 200. The fine aggregate resulting from the breakdown and natural sand should be stored in a separate reserve from the coarse aggregate above and protected against rain and the influence of water. The material must be a clean, hard material free from clay or other undesirable materials [4], [12].

(3) Filler: filler or filler material must pass filter no. 200. The filler should also be free from all unwanted materials. The added filler must be dry and free from lumps. The filler tested in this study was rock ash.

(4) Marshal Test: the basic principle of the Marshall method is checking stability and flow, as well as density and pore analysis of the solid mixture formed. In this case, the test object or solid asphalt concrete briquette is formed from the gradation of the mixed aggregate that has been obtained from the results of the gradation test, according to the specifications of the mixture. The Marshall test to obtain stability and flow followed [5].

\section{Results and Discussion}

\subsection{Bituminous Materials Testing}

The materials used for the asphalt concrete mixture in this study consisted of AC 60/70, Bantak coarse aggregate, Bantak fine aggregate, and filler from Bantak stone ash. From the results of the tests carried out on asphalt AC 60/70, the results are shown in Table 1 using the revision specification of [17]-[20], the complete data can be seen in Table 1.

Table 1. Experiment testing AC 60/70

\begin{tabular}{llcccl}
\hline No. & Testing procedures & Specifications & \multicolumn{2}{c}{ AC 60/70 } & units \\
\cline { 4 - 5 } & & & Mitra & Pertamina & \\
\hline 1. & Penetration $25^{\circ} \mathrm{C}$ & 60 to 79 & & 62.80 & $0.1 \mathrm{~mm}$ \\
2. & Softening point & 48 to 58 & & 53 & ${ }^{\circ} \mathrm{C}$ \\
3. & Flashpoint & $\geq 200$ & 322.67 & 228 & ${ }^{\circ} \mathrm{C}$ \\
4. & Burn point & & 324.67 & - & ${ }^{\circ} \mathrm{C}$ \\
5. & Specific gravity & $\geq 1$ & 1.034 & 1.031 & $\mathrm{gr} / \mathrm{cc}$ \\
\hline
\end{tabular}




\subsection{Bantak Characteristics}

Based on the specifications of the Revision of [18]. The test results on coarse aggregate, fine aggregate, and filler can be seen in Table 2 .

Table 2. Bantak performance testing

\begin{tabular}{lllcccc}
\hline No & Testing & Units & \multicolumn{2}{c}{ Requirements } & \multicolumn{2}{c}{ Results (temperature) } \\
\cline { 3 - 6 } & & & Min & Max. & $\mathbf{3 2}$ & $\mathbf{2 5}$ \\
\hline 1. & Abrasion & $\%$ & - & 40 & 34.57 & \\
2. & Bulk density & gr/cc & 2.5 & - & 2.306 & 2.301 \\
3. & Apparent density & gr/cc & 2.5 & - & 2.377 & 2.372 \\
4. & absorption & $\%$ & - & 3 & 3.100 & \\
& Fines aggregate & & & & & \\
& (Bantak) & & & & & \\
1. & Bulk density & gr/cc & 2.5 & - & 2.630 & 2.624 \\
2. & Apparent density & gr/cc & 2.5 & - & 2.903 & 2.897 \\
3. & Absorption & $\%$ & - & 3 & 3.573 & \\
& Filler (Bantak) & & & & & \\
& Specific gravity & Gr/cc & 2.5 & - & 2.565 & 2.559 \\
\hline
\end{tabular}

The test results using the Los Angeles machine show that the coarse aggregate used is resistant to abrasion. It can be seen from the average wear obtained, which is $34.57 \%$ or below the value required by the [18] is $40 \%$. Furthermore, Bantak fines aggregate test results showed a bulk density value of $2,630 \mathrm{gr} / \mathrm{cc}$. On correction with a temperature of $25^{\circ} \mathrm{C}$, the results are 2,624 $\mathrm{gr} / \mathrm{cc}$, or above the minimum value for bulk density. The required amount is $2.5 \mathrm{~g} / \mathrm{cc}$. The water absorption value of Bantak fine aggregate shows a value of 3,573\% or above the maximum value, which means that it exceeds the maximum required water absorption of $3 \%$.

\subsection{Stability test}

Marshall test results on hot asphalt concrete mixtures are density, stability, VMA (voids in mineral aggregate), VFA (voids filled in asphalt), VIM (voids in the mix), flow, and Marshall Quotient (MQ) on the specimens of each asphalt content of 3 test objects. Marshall test results as shown in Table 3.

Table 3. Stability test results

\begin{tabular}{llclllll}
\hline No & \multirow{2}{*}{$\begin{array}{c}\text { Testing } \\
\text { procedures }\end{array}$} & Specifications & \multicolumn{5}{c}{ AC 60/70 (\%) } \\
\cline { 4 - 7 } & & \multicolumn{1}{c}{$\mathbf{5}$} & \multicolumn{1}{c}{$\mathbf{5 . 5}$} & \multicolumn{6}{c}{$\mathbf{6}$} & \multicolumn{1}{c}{$\mathbf{6 . 5}$} & \multicolumn{1}{c}{$\mathbf{7}$} \\
\hline 1. & Density (gr/cm $\left.{ }^{3}\right)$ & & 2.31 & 2.31 & 2.32 & 2.33 & 2.33 \\
2. & VMA (\%) & $>13$ & 10.34 & 10.74 & 10.82 & 13.92 & 11.54 \\
3. & VFB (\%) & $>50$ & 9.27 & 24.10 & 38.60 & 60.10 & 66.14 \\
4. & VIM (\%) & $3.5-5.5$ & 9.39 & 8.2 & 6.67 & 5.20 & 4.20 \\
5. & Stability (kg) & $>800$ & 1320.37 & 1363.50 & 1317.67 & 1156.44 & 1100.61 \\
6. & Flow (mm) & $>3$ & 2.97 & 3.00 & 3.03 & 3.07 & 3.10 \\
7. & MQ (kg/mm) & $>250$ & 445.11 & 455.41 & 434.32 & 377.28 & 354.58 \\
\hline
\end{tabular}

The stability of the Marshall test is indicated based on the stability value. Stability is the ability of the pavement layer to withstand deformation due to traffic loads acting on it without changes in shape, such as waves and grooves. The stability value is influenced by the friction between the aggregate grains (internal friction), the locking between the aggregate grains (interlocking), and the good binding capacity of the asphalt layer (cohesion), besides that the compaction process, aggregate quality, and asphalt content also affect. 
Fig. 2 shows that the addition of asphalt of $5.5 \%$ increased by $3.27 \%$. Furthermore, at the addition of $6 \%, 6.5 \%$, and $7 \%$, the stability value decreased by $3.36 \%, 15.19 \%$, and $19.28 \%$, respectively to the $5.5 \%$. The value of Marshall Optimum stability is achieved in asphalt concrete mixtures with an asphalt content of $5.5 \%$ with an average stability value of $1363.50 \mathrm{~kg}$. Based on the Revision of [18] regarding the provisions on the properties of the laston mixture, the minimum stability value for heavy traffic is $800 \mathrm{~kg}$. All asphalt content used in this final project research meets the requirements.

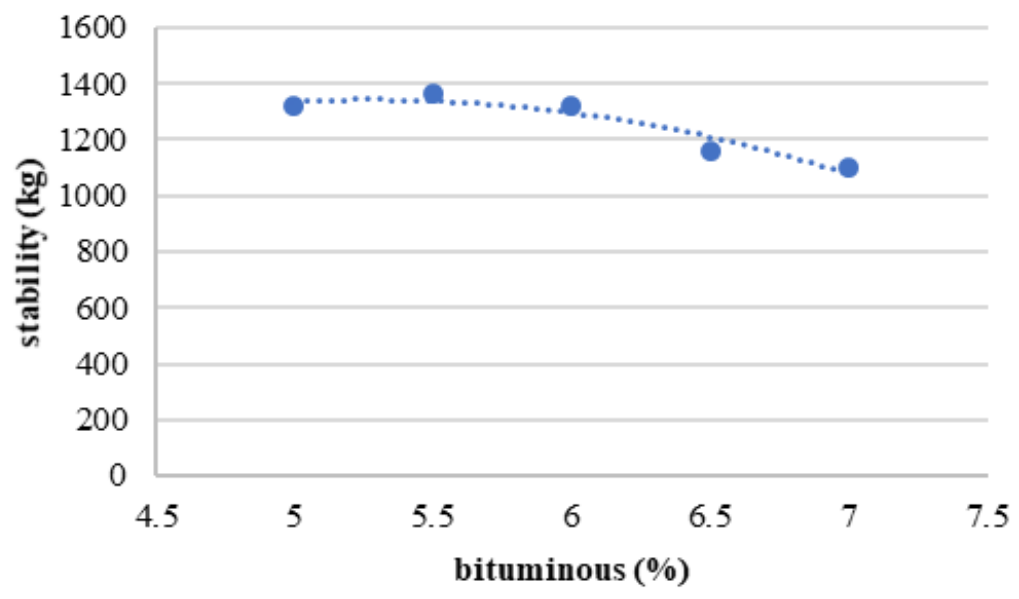

Fig.2. Stability versus bituminous (\%)

\subsection{Flow}

Flow or yield indicates the value of the decrease of deformation in the hard layer due to withstand the load it receives. The decrease or deformation that occurs is closely related to the values of other Marshall characteristics, such as VFB (Vold Filled Bitumen), VIM (Void in Mix), and their stability. The flow is influenced by aggregate gradation, asphalt content, and compaction process, which includes compaction temperature and compaction energy.

Low values and high stability direct to be stiff and brittle, while mixtures with high flow values and low stability tend to be plastic and easily deformed when subjected to traffic loads. Asphalt consists of two main components: asphaltenes and maltenes, in which asphaltenes give a brown or black color to Asphalt, while maltenes and oil also affect the flow value.

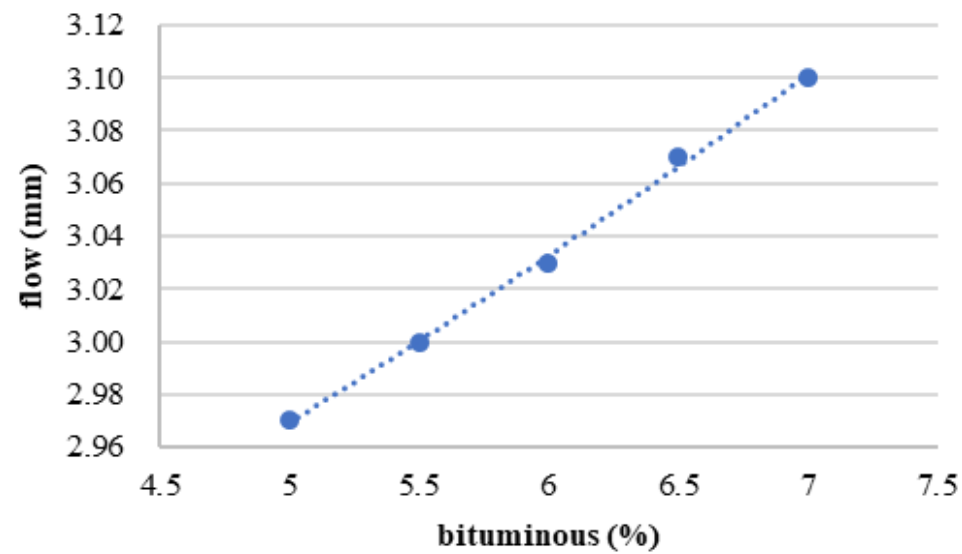

Fig.3. Flow versus bituminous (\%) 
In addition to the asphalt content of $5.5 \%, 6 \%, 6.5 \%$ and $7 \%$, the flow value increased, respectively, by $1.12 \%, 2.25 \%, 3.37 \%$ and $4.49 \%$ of the asphalt content. $5 \%$. Therefore, it can be concluded that the greater the asphalt content used, the flow value also increases. From the extent of the highest flow, there is an asphalt content of 7\%, with an average of $3.10 \mathrm{~mm}$. Meanwhile, if viewed from the Revision of [18] regarding the provisions on the properties of the laston mixture, the flow value must be $>3 \mathrm{~mm}$. The test results indicate that good agreement is $6 \%, 6.5 \%$, and $7 \%$ asphalt content.

\subsection{Void Filled Bitumen}

VFB (Void Filled Bitumen) states the process of air voids filled with asphalt in a mixture that has sustained compaction. This VFB value is based on the water and airtightness properties and the elastic properties of the mixture. The value of VFB is influenced by several factors such as energy, compaction temperature, type and content of asphalt, and aggregate gradation.

The greater the VFB value, the more air voids filled with asphalt so that the mixture's resistance to water and air will be higher. A VFB value that is too high will cause the pavement layer to bleed easily, or the asphalt rises to the surface.

A VFB (Void Filled Bitumen) value that is too small will cause the mixture's resistance to water to decrease due to a few voids filled with asphalt. With many empty cavities, water and air will quickly enter the hard layer so that the durability of the hard layer will be reduced.

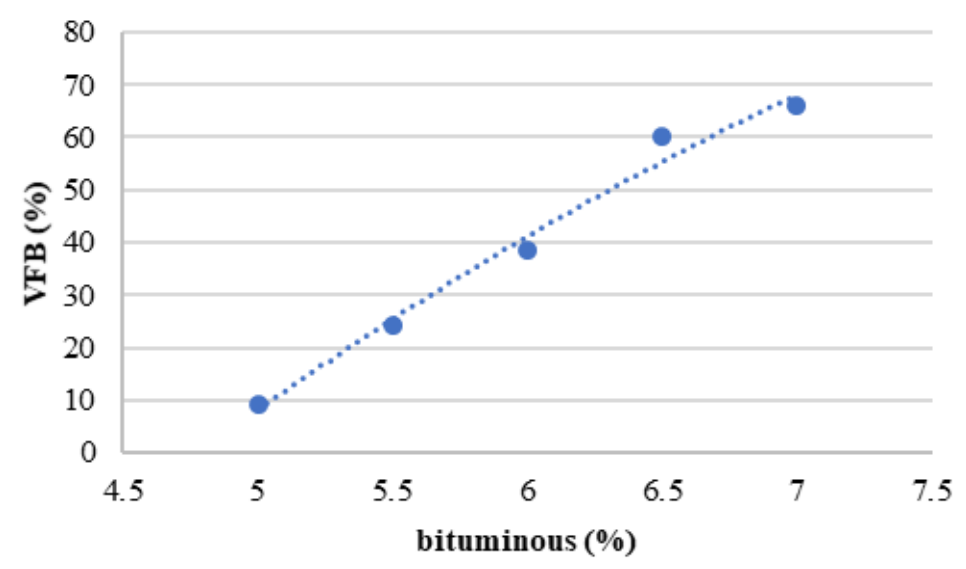

Fig.4. VFB versus bituminous (\%)

The VFB value at 5\% asphalt content was 9.27\%, at each addition of $5.5 \%, 6 \%, 6.5 \%$ and $7 \%$ asphalt content. The VFB increased successively by $24.10 \%, 38.60 \%, 60.10 \%$, and $66.14 \%$, respectively. Hence, it can be concluded that the higher the asphalt content of VFB. From Fig. 3, the highest VFB was obtained at $7 \%$ asphalt content with a value of $66.14 \%$.

Based on the requirements of [18] regarding the provisions on the properties of the laston mixture, the VFB (Void Filled Bitumen) value must be $>60 \%$. The VFB matches the requirements, particularly the asphalt content of $6.5 \%$ and $7 \%$, satisfy the requirements with $60.10 \%$ and $66.14 \%$.

\subsection{Voids In Mix (VIM)}

VIM (Void in Mix) is the number of voids in the mixture expressed in percentage. The air voids contained in the mixture are needed to provide space for the elements of the mixture according to the elastic properties. Therefore, the value of VIM greatly determines the 
characteristics of the mixture. VIM is influenced by aggregate gradation, asphalt content, and density.

If the VIM value is too high, the durability of the hard layer will decrease because the cavity is too large, which will facilitate the entry of water and air into the pavement layer. The air will oxidize the asphalt so that the asphalt blanket becomes thinner and the asphalt cohesion is reduced. If this happens, it will cause the release of granules (raveling), while the water will dissolve the part of the asphalt that is not oxidized so that the reduction in the amount of asphalt will be faster.

A VIM value that is too low will cause easy bleaching of the hard layer. In addition to bleeding, with a low VIM, the stiffness of the hard layer will crack when it receives traffic loads because it is not flexible enough to accept the deformation that occurs.

Fig. 5 shows that the VIM (Void in Mix) value is obtained at 5\% asphalt content with an average of $9.39 \%$, with the addition of asphalt content of 5.5\%, 6\%, 6.5\%, and 7\%. VIM (Void in Mix) decreased successively with an average of $8.20 \%, 6.67 \%, 5.20 \%$, and $4.20 \%$. Hence, it can be concluded that the greater the asphalt content used, the lower the VIM. From Fig. 5, the highest VIM (Void in Mix) value is found at 5\% asphalt content with an average of 9.39\%.

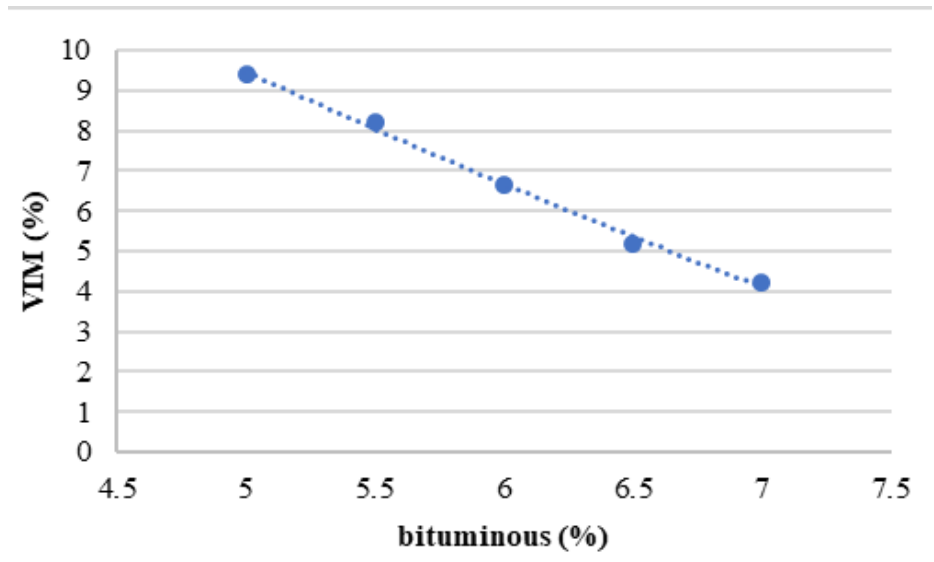

Fig.5. VIM versus bituminous (\%)

Based on the requirements of the Revision of [18], regarding the provisions of properties of Laston mixture, the VIM value that matches the requirements is $3.5 \%-5.5 \%$. The VIM values that meet the requirements are $6.6 \%$ and $7 \%$ asphalt content, with an average of 5.20\% and 4.20 .

\subsection{VMA (Void In Mineral Aggregate)}

VMA (Void in Mineral Aggregate) is an air cavity between mineral aggregates in the hot asphalt mixture that has been obtained, including the space filled with asphalt. VMA is expressed as a percentage of hot mix asphalt. VMA is used to accommodate asphalt and the volume of air voids required in hot asphalt mixtures. The value of VMA is influenced by asphalt content, gradation of stacking material, number of collisions, and compaction temperature. The relationship between VMA and asphalt content can be seen in Fig. 6. 


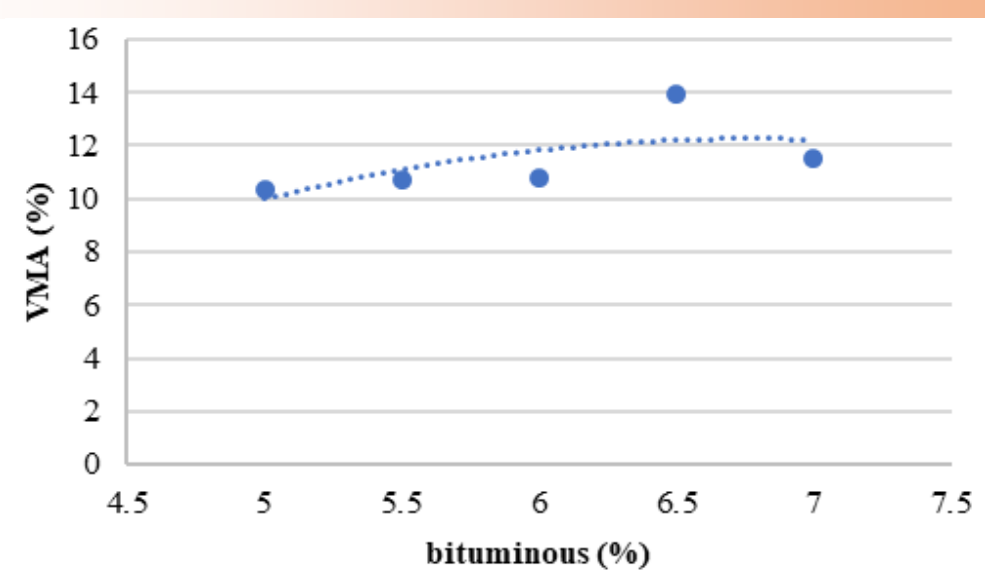

Fig.6. VMA versus bituminous (\%)

The VMA (Void in Mineral Aggregate) at 5\% asphalt content with an average of 10.34\%, and asphalt content of $5.5 \%, 6 \%$, and $6.5 \%$ increased $10.74 \%, 10.82 \%$, and $13.92 \%$. While the addition of $7 \%$ asphalt content decreased by an average of $11.54 \%$. Referring to the Revision of SNI 03-1737-1989 [18] concerning the provisions for the properties of the Laston mixture, the minimum VMA value is $>13 \%$, so the VMA (Void In Mineral Aggregate) value that meets the requirements is $6.5 \%$ with an average of $13.92 \%$.

\subsection{Marshall Quotient (MQ)}

The value of Marshall Quotient (MQ) is the quotient between stability and fatigue (flow) and is an approach to the level of stiffness and flexibility of the mixture. The larger the value of QM means the mixture is getting stiffer, and conversely. The smaller of QM, the more flexible the pavement.

Fig. 7 shows the relationship between MQ and asphalt content. The addition of asphalt content of $5.5 \%$ increased by $2.31 \%$, when the addition of asphalt content of $6 \%, 6.5 \%$, and $7 \%$ the value of MQ decreased by $4.63 \%, 17.16 \%$, and $22.14 \%$, to $5.5 \%$, respectively. Fig. 6 shows that the asphalt concrete mixture with an asphalt content of 5.5\% has a maximum MQ (Marshall Quotient) value of $455.10 \mathrm{~kg} / \mathrm{mm}$. The asphalt concrete mixture using Bantak aggregate satisfies the MQ requirements based on the Revision of [18] > $250 \mathrm{~kg} / \mathrm{mm}$.

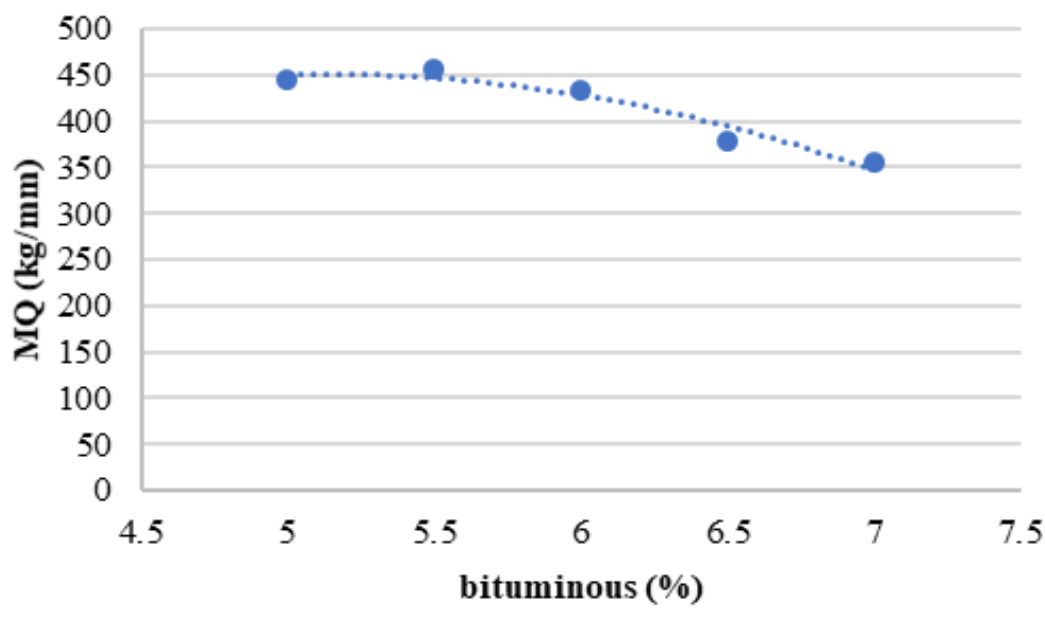

Fig.7. MQ versus bituminous (\%) 


\section{Conclusion}

The test results show that the characteristics of Bantak aggregate in terms of stability, flow, VFB, VIM, VMA, and MQ tests satisfy the test requirements for materials in medium and heavy traffic. However, this test needs to be analyzed to describe the pattern of material damage on a discrete element method as proposed by [21]-[23] for homogeneous or non-homogeneous materials. It is important because in a series of experiments, the damage pattern is speedy, and the reading is only based on a set of existing equipment. Therefore, to avoid errors in reading, it is advantageous to have a comparison variable to develop the test sequence for better results.

\section{Acknowledgment}

The authors would like to thank the Department of Civil Engineering and Planning for laboratory facilities, testing, and data analysis and the entire international research team who has provided analysis, advice and has been involved in this project.

\section{References}

[1] F. Ma'arif and Pramudiyanto, "Uji kinerja Marshall agregat Bantak Merapi dengan menggunakan serat polypropylene," INERSIA, vol. 10, no. 1, 2014, doi: https://doi.org/10.21831/inersia.v10i1.4424.

[2] F. Ma'arif, "Efek variasi kadar bitumen terhadap kinerja Marshall laboratorium dengan menggunakan agregat Bantak (studi kinerja agregat Bantak dengan menggunakan emulsi, modifikasi polymer, AC 60/70 dan Shell (Singapore) pada lalulintas berat)," INERSIA, vol. 2, no. 8, 2012, doi: https://doi.org/10.21831/inersia.v8i2.3999.

[3] B. Wang, X. Hu, Y. Shao, O. Xu, P. Lu, and K. Li, "Modelling and testing of Temperature-Dependent strength and toughness of asphalt concrete from $-10{ }^{\circ} \mathrm{C}$ to $+23{ }^{\circ} \mathrm{C}$ using small notched beams," Construction and Building Materials, vol. 294, p. 123580, Aug. 2021, doi: 10.1016/J.CONBUILDMAT.2021.123580.

[4] A. M. Rashad, S. A. Khafaga, and M. Gharieb, "Valorization of fly ash as an additive for electric arc furnace slag geopolymer cement," Construction and Building Materials, vol. 294, p. 123570, Aug. 2021, doi: 10.1016/J.CONBUILDMAT.2021.123570.

[5] G. P. Piuzzi, H. C. Scheuermann Filho, J. A. Villena Del Carpio, and N. C. Consoli, "The effects of porosity, asphalt content and fiberglass incorporation on the tensile strength and resilient modulus of asphalt concrete blends," Geotextiles and Geomembranes, vol. 49, no. 3, pp. 864-870, Jun. 2021, doi: 10.1016/J.GEOTEXMEM.2021.01.002.

[6] S. Ullah, M. Raheel, R. Khan, and M. Tariq Khan, "Characterization of physical \& mechanical properties of asphalt concrete containing low- \& high-density polyethylene waste as aggregates," Construction and Building Materials, vol. 301, p. 124127, Sep. 2021, doi: 10.1016/J.CONBUILDMAT.2021.124127.

[7] T. Takaikaew, M. Hoy, S. Horpibulsuk, A. Arulrajah, A. Mohammadinia, and J. Horpibulsuk, "Performance improvement of asphalt concretes using fiber reinforcement," Heliyon, vol. 7, no. 5, p. e07015, May 2021, doi: 10.1016/J.HELIYON.2021.E07015.

[8] K. Yildiz and M. Atakan, "Improving microwave healing characteristic of asphalt concrete by using fly ash as a filler," Construction and Building Materials, vol. 262, p. 120448, Nov. 2020, doi: 10.1016/J.CONBUILDMAT.2020.120448.

[9] T. P. Pangestu, W. A. Ahmad, A. S. Bawono, and M. Aqifd, "The performance of stability test using Bantak aggregate and AC50/70 as polymer on Marshall characteristic," Journal of Engineering and Applied Technology, vol. 1, no. 2, pp. 97109, Mar. 2020, doi: 10.21831/JEATECH.V1I2.39232.

[10] A. Khalim, H. U. Ghifarsyam, N. Rozy, and F. Ma'arif, "Scheduling design of Jakarta- 
Cikampek II elevated toll road project (P. 186-P. 187)," Journal of Engineering and Applied Technology, vol. 2, no. 1, 2021, doi: https://doi.org/10.21831/jeatech.v1i2.34957.

[11] D. A. U. Ilma, F. Fitriyanti, F. Ma'arif, N. Baldah, and B. Utoyo, "State of the art perselisihan kontrak konstruksi di Indonesia," INERSIA, vol. 16, no. 2, pp. 158-170, 2020, doi: https://doi.org/10.21831/inersia.v16i2.36901.

[12] Badan Standarisasi Nasional Indonesia, SNI 03-1968-1990 Metode Pengujian Analisa Saringan Agregat Halus dan Agregat Kasar. Jakarta: Badan Standarisasi Nasional, 1992.

[13] Badan Standarisasi Nasional Indonesia, SNI 03-2417-1991 Metode Pengujian Keausan Agregat Dengan Mesin Abrasi Los Angeles. Jakarta: Badan Standardisasi Nasional Indonesia, 1991.

[14] Badan Standarisasi Nasional Indonesia, SNI 06-2441-1991 Metode Pengujian Berat Jenis Aspal. Jakarta: Badan Standardisasi Nasional Indonesia, 1991.

[15] American Association of State and Highway Transportation Officials, AASHTO M 20-70 (2004) Standard Specification for Penetration-Graded Asphalt Cement. 2004.

[16] American Association of State Highway and Transportation Officials (AASHTO), AASHTO T 84: Standard Method of Test for Specific Gravity and Absorption of Fine Aggregate. American Association of State Highway and Transportation Officials (AASHTO), 2013.

[17] Badan Standarisasi Nasional Indonesia, RSNI M-01-2003 Metode Pengujian Campuran Beraspal Panas dengan Alat Marshall. Jakarta: Badan Standardisasi Nasional Indonesia, 2003.

[18] Badan Litbang Departemen Pekerjaan Umum, Revisi SNI 03-1737-1989. Pedoman Tentang "Pelaksanaan Lapis Campuran Beraspal Panas" adalah Pengganti dari SNI 03-1737-1989, Tata Cara Pelaksanaan Laapis Aspal Beton (LASTON) untuk Jalan Raya. Badan Litbang Departemen Pekerjaan Umum.

[19] Badan Litbang Departemen Pekerjaan Umum, Revisi SNI 06-2456-1991 Uji Penetrasi Aspal. Jakarta: Badan Litbang Departemen Pekerjaan Umum.

[20] Badan Litbang Departemen Pekerjaan Umum, Revisi SNI 06-2434-1991. Cara Uji Titik Lembek Aspal Dengan Alat Cincin Dan Bola (Ring Ang Ball). Jakarta: Badan Litbang Departemen Pekerjaan Umum.

[21] F. Ma'arif, Z. Gao, and F. Li, "Investigation of concrete quality using Discrete Element Method (DEM)," Journal of Physics: Conference Series, vol. 1833, no. 1, p. 012053, Mar. 2021, doi: 10.1088/1742-6596/1833/1/012053.

[22] F. Ma'arif, Z. Gao, and F. Li, "The modeling of compressive strength of concrete on discrete element method," Journal of Physics: Conference Series, vol. 1845, 2020.

[23] F. Ma'arif, Z. Gao, and F. Li, "A review of the discrete element method application on concrete materials," Journal of Physics: Conference Series, vol. 1625, no. 1, p. 012009, Sep. 2020, doi: 10.1088/1742-6596/1625/1/012009. 